\title{
Brand Ambassador and Customer Patronage of FMCGs: Mediating Effect of Advertisement Believability
}

\author{
Mustapha Yusuf Ismaila \\ ismyoriss@gmail.com \\ Issa Binta Oziohu \\ Bintaisah60@yahoo.com
}

\begin{abstract}
The market for fast-moving consumer goods (FMCGs) in the Nigerian food and beverage industry has been inundated with a massive amount of promotional messages. These messages have resulted from intense competition and rivalry among the organizations that market similar products. The objective of this study is to evaluate the effect of a brand ambassador on the patronage of FMCGs. Furthermore, we explore the mediating role of advertisement believability in the relationship between the variables. We use a questionnaire to elicit information from 400 respondents who are members of households in the metropolitan area of Kano that consumed Peak milk. Partial least square algorithms and bootstrapping techniques served as the tools of analysis with the aid of SMART-PLS 3. Our findings indicate that a brand ambassador has an insignificant direct effect on customer patronage and that advertisement believability has no mediating effect on the influence of a brand ambassador on customer patronage. The study recommends that managers of FMCGs should use a hybrid model of a brand ambassador and believable advertising to elicit the desired patronage from their target customers. Further, they should de-emphasis the supposed role of advertisement believability as a mediating factor on the influence of a brand ambassador on customer patronage.
\end{abstract}

Keywords: Brand Ambassador, Customer, Customer Patronage, FMCGs, Mediating Effect 


\section{Embajador de marca y patrocinio de clientes de bienes de consumo masivo: efecto mediador de la credibilidad del anuncio}

Mustapha Yusuf Ismaila

ismyoriss@gmail.com

Issa Binta Oziohu

Bintaisah60@yahoo.com

\section{Resumen}

El mercado de bienes de consumo de rápido movimiento en la industria de alimentos y bebidas de Nigeria, se ha visto inundado con una gran cantidad de mensajes promocionales. Estos mensajes son el resultado de una intensa competencia y rivalidad entre las organizaciones que comercializan productos similares. El objetivo de este estudio es evaluar el efecto de un embajador de marca en el patrocinio de bienes de consumo masivo. Además, exploramos el papel mediador de la credibilidad de la publicidad en la relación entre las variables. Usamos un cuestionario para obtener información de 400 encuestados que son miembros de hogares en el área metropolitana de Kano que consumieron leche Peak. Los algoritmos Partial least square y las técnicas bootstrapping sirvieron como herramientas de análisis con la ayuda de SMART-PLS 3. Nuestros hallazgos indican que un embajador de marca tiene un efecto directo insignificante en el patrocinio del cliente y que la credibilidad de la publicidad no tiene un efecto mediador sobre la influencia de un embajador de la marca en patrocinio del cliente. El estudio recomienda que los gerentes de bienes de consumo masivo deben utilizar un modelo híbrido de embajador de marca y publicidad creíble para obtener el patrocinio deseado de sus clientes objetivo. Además, deberían restar importancia al supuesto papel de la credibilidad de la publicidad como factor mediador en la influencia de un embajador de la marca en el patrocinio del cliente. 


\section{Introduction}

Marketers see advertising as a communication tool that they can use to induce customers to patronize specific products. This is despite that some customers still view advertising as a deceptive, unreliable, and misleading approach that attempts to influence their buying behavior, especially when an unknown source is transmitting the advertisement. Garrett (2020) supports this position when he observed that customers were less responsive to mainstream advertisements these days unless they came from a credible and reliable source (endorser). Hence, the use of honest, credible, and reliable spokespeople can bridge this trust deficit between marketers' product advertisements and buyers' believability of such messages. Garrett (2020) further observes that influencers offered a focus ground because they could relate to the customers and help familiarize them with the products. Consequently, the endorsers' credibility would eventually lead to increasing purchase intentions by target customers (Mookda, Khan, Intasuwan \& Chotchoung, 2020).

Therefore, the need to relate advertising to customers which will result in a certain degree of believability in a competitive marketing environment accounts for why marketing organizations are now using influencers to endorse their products. Carrillat, O'Rourke and Plourde (2019) have maintained that celebrity endorsements generally have constructive effects on brand attitudes, purchase decisions, merchandise sales, and stock value. Indeed, a number of scholars in this area such as Tehreem and Rizwan (2016), Daha, Acheampong, Bakare and Amanathan (2018), Fachri (2018), Garrett (2020) and Mustapha, Issa and Bello (2021) have attested to the potency of endorsements by brand ambassadors as a vital advertisement tool for influencing the buying decision of customers. More so, Lim, Chock, and Golan, (2020) have asserted that celebrity endorsement is one of the most regularly used persuasion tool in the marketing world today, while Mookda, Khan, Intasuwan and Chotchoung (2020) have argued that endorsements by celebrities or brand ambassadors are persuasion tools that marketers can use to influence or persuade target audiences to purchase their products.

The food and beverage industry is part of the fast-moving consumer goods (FMCGs) market. This market is very huge and competitive in nature and has high revenues compared to other sectors of the Nigeria economy. FMCGs are products that sell speedily at moderately low prices, and the industry refers to them as consumerpackaged products. For example, some FMCG producers in Nigeria are Friesland Campina WAMCO Nigeria PLC, Cadbury Nigeria PLC, Nigerian bottling company, Unilever, Procter and Gamble, Nestlé, and 7UP Bottling company. The brands in the milk subsector of the industry are Peak milk, Coast milk, Cowbell milk, Three crown, Hollandia milk, Dano milk, and Nunu milk. These companies compete in their characteristics of creaminess, taste, and quality. The potential of this industry in Nigeria has led to the proliferation of similar products that has resulted in intense competition and rivalry among the companies. This situation has stimulated companies to use brand ambassadors as a marketing strategy to attract customers to their products. Therefore, endorsements from brand ambassadors or celebrities has become a popular marketing strategy worldwide that benefits companies that use celebrities' fame to endorse their goods (Carlson, Donavan, Deitz, Bauer, \& Lala, 2020). 
A review of earlier studies provides varying results linked to the subject matter. For instance, Gaofu, Yating and Jing (2018), Radhi, Halim, Ratih and Mokh (2019), and Mustapha, Issa and Bello (2021) have found that the credibility and reputation of the image spokesmen have a direct and positive effect on customers' attitudes by reflecting a higher quality, greater value, and worthiness of the products. Moreover, the studies of Lubna (2018) and Safi, Azouri and Azouri (2018) have found that endorsers who are physically attractive are more persuasive in changing customers' ideas and creating buying intentions than unattractive ones. Arising from the foregoing, Friesland Campina WAMCO Nigeria PLC that is the producer of Peak milk has committed huge resources to a brand ambassador in order to win and retain customers. For instance, it engaged the "tournament hero" Kanu Nwankwo to endorse its products because of his credibility, reliability and popularity on the field of play in 1996 and 2013 after the Nigerian U-20 team and Super Eagles won the Olympic tournament in the USA and the Africa cup nation in South Africa respectively.

However, how successful this strategy was for companies like Friesland Campina WAMCO Nigeria PLC has not been adequately investigated by empirical studies. Hence, this gap provides us with the opportunity to add to the body of knowledge in this area. Specifically, we evaluate the effects of two dimensions of brand ambassadors (i.e., credibility and popularity) on the patronage of FMCGs' products. We also explore whether advertisement believability plays a mediating role in the relationship between the variables under study.

\section{Review of literature}

Everyone is a consumer as we all buy one thing or another almost on daily basis. We all consume and buy products according to our needs, preferences, and buying power; these purchases could be consumable goods, durable goods, specialty goods, or industrial goods (Matin, 2006). A consumer is someone who enjoys the benefit of a product (Blythe, 2013). The Consumer Protection Act (2008) states that consumers are people to whom firms market goods or services; they are people who have entered into transactions with suppliers and who are users of particular goods or services. Everyone who is engaged in the consumption process is a consumer (Jisana, 2014). Salomon, Bamossy, Askegaard and Hogg (2006) opine that a consumer is generally thought of as a person who identifies a need or desire, makes a purchase, and then disposes off the product during a three-stage consumption process: pre-purchase, purchase, and postpurchase.

Customer patronage is the study of individuals, groups, or organizations and the processes involved in selecting, using, and disposing of products, services, experiences, or ideas to satisfy needs and the effects that these processes have on the consumer and society (Sushil \& Ashish, 2013). In the opinion of Giridhar (2012), customer patronage involves studying the personality of individual consumers which include demographics, psychographics, and behavioral variables in an attempt to understand people's wants. From these definitions therefore, the customers of Friesland Campina WAMCO Nigeria PLC's Peak milk are the focus of this study, and they are either an individual household or group of individuals who consume Peak milk products. 
The use of a public figure, who has charisma and the ability to attract people's hearts and their attention, to promote and advertise a product is called a brand ambassador (Soesatyo, 2013). A company chooses a brand ambassador to be the face of the brand. Ideally, the candidate is a tastemaker in their communities who uses already established networks and relationships to market the brand. This marketing can occur via word-ofmouth and posting online to refer the brand to friends (Ben \& Melissa, 2020). The chosen public figure is usually an attractive individual (Luh, Sari, Natasya \& Hotlan, 2020). Lisa and Astrid (2018) posit that the use of brand ambassadors is important for companies in order to introduce their products to the society at large as well as to increase their revenue. Lisa and Astrid have found that the existence of a brand ambassador indirectly attracts the attention of the potential customers. Thus, this indirect effect indicates that a brand ambassador can generate appeal for the consumers and potential customers.

Ambassadors have definitional components that are a range of socially desirable personal attributes and skills which lead to the widespread recognition and creation of popular and influential individuals (Marcela, John, Sandra \& Piyush, 2019). For example, soccer specialists and enthusiasts concur that Kanu Nkwankwo is a very credible and reliable footballer. He uses the popular recognition of his soccer skills to support his endorsed brand. As a brand ambassador, he similarly represents the companies at specific events at which he may perform product demonstrations or give away sample products (Ben \& Melissa, 2020). Companies use brand ambassadors to influence consumers by getting their attention to use the product. Their use is usually based on people's imaging of a well-known public figure (Luh, Sari, Natasya \& Hotlan, 2020). Therefore, customer patronage may be influenced by the qualities and relevance of the brand ambassador.

Whether customers believe an advertisement is contingent on their confidence in its frankness (Beltramini, 1982). Beltramini (1982) has opined that advertisement believability simply refers to the degree to which an advertisement can arouse adequate confidence in customers on its truthfulness and consequently, its acceptability. Thus, the concept of advertisement believability proposes that advertisements must be able to stand up to the scrutiny of the skeptic and elicit a positive respond.

Griffin and Cass (2003) have observed that believability is a significant factor in customers' intention and decision to positively react to the advertisement. Beltramini and Kenneth (1985) support this position and opine that the believability of the advertisements is vital because it has a strong influence on their effectiveness and the buyers' intention to respond. However, an advertisement on its own does not have inherent influence but depends on the interaction between it and the consumers' attitude and accumulated memories from the previous experiences.

\section{Brand Ambassador and Consumer in Nigeria}

The era of signing brand ambassadors in Nigeria began a little over two decades ago and has gained prominence across industries. This prominence is not surprising considering the unprecedented exposure of consumers to advertising on social media platforms, television, and radio stations. Therefore, managers in the food and beverage industry have engaged professionals and other celebrities in their advertising to position and differentiate their products in the minds of their target customers. 
In Nigeria, a brand ambassador's status comes from career success in the fields such as sports, health, and entertainment. For instance, from the sporting arena we have the likes of Anthony Joshua, Kanu Nwankwo, Austin Okocha, and Ahmad Musa, while from the stable of Nollywood stars we have actors and actresses such as Ini Edo, Genevieve, Kanayo, Omotola, Ramsey Nouah, Richard Mofe Damijo, Desmond Elliot, Olu Jacobs, Pete Edochie, Dakore Akande, Ali Nuhu, Rhama Sadau, and Sanni Danger in Nigeria. Different companies have used these famous personalities as brand ambassadors to promote their products. Business companies normally use celebrity attributes such as extraordinary credibility, physical attractiveness, popularity, availability, product-match, and target audience-match to promote their products to the target audience (Anas \& Pradipta, 2018; Aamir, Gul, Iqra \& Laila, 2018). These distinctive attributes account for the reason why different brand ambassadors are engaged by different firms.

\section{Brand Ambassadors' Credibility and Attractiveness, and Customer Patronage}

The credibility and reputation of the brand ambassador have direct and positive effects on consumers' attitudes (Gaofu, Yating \& Jing, 2018). Thus, high credibility reflects a higher quality, greater value, and worthiness of the product that leads to a more positive behavior from consumers (Radhi, Halim ,Ratih, \& Mokh, 2019). Similarly, Phaik, Salmi and Yasmin (2019) have argued that consumers agree that the trustworthiness of the source of a brand is the most important factor in its credibility. Garrett (2020) has discovered that customers concur that their decisions to purchase products are affected by endorsements from brand ambassadors with esteem and integrity. Brand ambassadors are able to establish their credibility online and to affect consumer behavior that in turn allows their brand partners to enjoy the benefits (Garrett, 2020).

A brand ambassador's physical attractiveness does arouse the attention of many customers and it is not only limited to the size of the body but also consists of all physical features such as hair color, facial features as well as physical appearance (Pui Yi, 2012). Attractiveness affects consumer behaviors in the sense that they want to look attractive and stylish like these ambassadors (Qureshi \& Malik, 2017). For instance, if young men and women find Super Eagle star Ahmed Musa in a beautiful jersey and attractive hairdo, these attributes will influence their feeling toward the brands he endorses. Researchers like Lubna (2018) and Safi, Azouri and Azouri (2018) have proven that brand ambassadors who are physically attractive are more persuasive in changing consumers' ideas and creating buying intentions than unattractive ones. Consumers perceive the brand as having superior quality because an attractive source endorses it (Soniya \& Santhosh, 2018). The study of Benita and Gordon (2018) shows that the brand ambassador's attractiveness is positively correlated with consumers' buying behavior and that attractiveness can make an advertisement smarter and catchy. Similarly, Marium (2018) has stated that a brand ambassador who is perceived to be an expert by the consumers has more persuasion on the purchase intention than one who is considered to be attractive. Contrarily, the study of Fachri (2018) has discovered that brand ambassador's attractiveness has no significant effect on consumer behavior.

Melinda et al (2016) carefully examined the recall and believability of the practical tips from a smokers campaign among university students. The findings of the study showed that the believability of one or more advertisements was lower for male undergraduates. 
The study found that believability was equally greater for those who recalled seeing the advertisements more often while subgroups of the respondents reported less believability. Bagheri and Biglari (2020) explored the role of consumers' attitude in the believability of commercial advertisements by athlete endorsers and discovered significant and positive relationships among the five components of attitudes to advertising and its believability. The consumers' attitudes on advertising had a direct and significant effect on its believability. Kim and Kim (2021) carefully investigated spatial distance and message strategies in cause-related marketing to influence consumers' believability of and attitudes to advertisements. Their study discovered a mediating role of advertisement believability between cause proximity and message strategy on customers' attitude toward the advertisement. Fenech (2020) examined the factors that affect advertisement credibility of and visit intention to restaurants in the social media environment. The result indicates that different social media advertisements have a greater effect on a restaurant's credibility and visit intention, while other elements have a weaker effect.

\section{Hypotheses Development}

On the basis of the reviewed literature, this study proposes the following research hypotheses:

H01: Brand ambassadors do not have a significant effect on the customer patronage of Peak milk products in the metropolitan area of Kano.

H02: Advertisement believability does not mediate the effect that brand ambassadors have on the customer patronage of Peak milk in the metropolitan area of Kano.

Theory of the Study.

\section{Social Comparison Theory (SCT)}

According to Festinger (1954), the social comparison theory (SCT) argues that people will compare themselves to others with a common goal. This idea helps to measure how they develop their marketing competencies. Jaiswal and Gupta (2015) argue that behavioral scientists have long espoused the idea that individuals liken themselves to others to exact self-assessment, self-upgrade, and self-change. The proponents of this theory see it as a critical choice where people consider and choose norms for comparison purposes. For instance, when customers' interests are focused on a decision to purchase a product, they will purposely compare themselves to individuals who they see as alike that then affirms their decision and settles their self-assessment. Social comparison exists since individuals think about how others will respond to or see their activities (Albert, Ambroise \& Valette-Florence, 2017). Hence, the SCT presumes that individuals will compare themselves with a brand ambassador who possesses the attributes that are appealing to them.

Theory of Celebrity Credibility 
This model was developed by the Hovland and Weiss (1951). They classified the theory as pertaining to trustworthiness and expertise. They argue that trustworthy and expert celebrities have a greater positive effect on the buying behavior of the target audience. Ohanian (1990) supports this claim. The effectiveness of an advertisement depends on the perceived extent of the knowledge, reliability, and credibility of the celebrity (Mikuláš and Světlík, 2016). This theory argues that the transmission of information from a credible and reliable source has the capability of having a favorable effect on the believes, opinions, reviews, attitudes, perceptions, and responses of consumers through the process of internalization (Mikuláš and Světlík, 2016). Thus, the credibility of a spokesperson is based on the perception of consumers that the information given by the celebrity spokesperson is unbiased, trustworthy, and reliable.

\section{METHOD}

In this study we adopted a survey. The target population consists of all the households that consumed Peak milk in the metropolitan area of Kano. The population totals 3,391,300 residents (NBS, 2019) spread across Nasarawa, Tarauni, Kumbatso, Kano city, Gwale, Fagge, Ungogo, and Dala local government areas (LGAs). Eligible respondents to the survey are required to be at least 18 years old. The sample size was calculated at 400 by using the Yamane (1967) formula. The experiment was conducted through a questionnaire administered to respondents with a combination of random and convenience sampling techniques from the eight LGAs. This technique is considered suitable because data can be quickly and easily collected and the technique is inexpensive to conduct. The instrument was separated into four sections: the first section dealt with the profile of the respondents while sections 2-4 dealt with brand ambassador constructs (independent variable), customer patronage constructs (dependent variable), and advertisement believability constructs (mediating variable).

SMART-PLS was used for data analysis through a measurement model and structural equation modeling. The data were examined to determine their reliability, internal consistency reliability, composite reliability, and average variance extracted (AVE) under the measurement model, while the relationships between the study's constructs were scrutinized on the basis of the SEM that used the collected data. In line with the suggestion of Hair, Hult, Ringle, and Sarstedt (2016), we used the internal consistency method to determine the reliabilities of the constructs in the questionnaire.

\section{ANALYSIS AND DISCUSSION OF RESULTS}

This section presents the results of the study.

Table 1: Cronbach's Alpha, Composite Reliability and AVE

\begin{tabular}{llll}
\hline Variables & Cronbach's Alpha & Composite Reliability & AVE \\
\hline ADB & 0.734 & 0.852 & 0.560 \\
CP & 0.813 & 0.893 & 0.525 \\
BA & 0.765 & 0.816 & 0.544 \\
\hline
\end{tabular}

Source: Survey Results, 2020 
Table 1 presents the Cronbach's alpha, composite reliability, and AVE. The Cronbach's alpha coefficients and composite reliability values are all above 0.7 and are within acceptable ranges. Furthermore, the validity of the study's constructs was assessed through discriminant validity that is in line with the criteria suggested by Fornell and Larcker (1981) and Hair, Black, Babin and Anderson (2010). The AVE values in the above table range from 0.525 to 0.560 which indicates acceptable values. According to Hair Jr, Hult, Ringle and Sarstedt (2016), Cronbach's alpha and composite reliability should be higher than 0.7 , while AVE values must be higher than 0.5 for each to be statistically acceptable.

Table 2: Latent Variables Correlations and Square Roots of AVE

\begin{tabular}{lrcc}
\hline Variables & ADB & CP & BA \\
\hline ADB & $\mathbf{0 . 7 4 8}$ & & \\
CP & 0.690 & $\mathbf{0 . 7 2 5}$ & \\
BA & -0.163 & -0.198 & $\mathbf{0 . 7 3 8}$ \\
\hline
\end{tabular}

Source: Survey Results, 2020; advertisement believability (ADB), customer patronage $(\mathrm{CP})$, and brand ambassador (BA)

Table 2 presents the discriminant validity that relates the correlation among the variables. According to Fornell and Larcker (1981), the square root of the AVE should be higher than the correlation value with other variables. The square root of the AVE is normally shown diagonally in a table, that is, the first value of each column is higher than the other values, which satisfies the condition of discriminant validity.

Table 3: Coefficient of Determination $\left(R^{2}\right)$

\begin{tabular}{llll}
\hline Variable & Variable Type & R Square & R Square Adjusted \\
\hline ADB & Endogenous & 0.611 & 0.542 \\
CP & Endogenous & 0.637 & 0.631 \\
\hline
\end{tabular}

Source: Survey Results, 2020; advertisement believability (ADB) and customer patronage (CP)

Table 3 presents the values of the coefficient of determination (R2) for the endogenous variables; they are 0.611 and 0.637 respectively for advertisement believability and customer patronage and have a moderate predictive quality.

Table 4: Assessment of the Effect Size $\left(\mathrm{f}^{2}\right)$

\begin{tabular}{lll}
\hline Variables & $\mathbf{f}^{\mathbf{2}}$ & Effect Size \\
\hline $\mathrm{ADB}$ & 0.801 & Significant \\
$\mathrm{CP}$ & 0.031 & Insignificant \\
\hline
\end{tabular}

Source: Survey Results, 2020; advertisement believability (ADB) and customer patronage $(\mathrm{CP})$

Table 4 gives the assessments of the effect size of advertisement believability (ADB) and brand ambassador (BA) as 0.801 and 0.031 respectively. The outcome of this assessment as contained in the table shows that ADB has a significant effect on CP. 
Table 5: Assessment of Predictive Relevance (Q2)

\begin{tabular}{llll}
\hline Endogenous Variables & SSO & SSE & $\mathbf{Q}^{\mathbf{2}}$ (=1-SSE/SSO) \\
\hline $\mathrm{ADB}$ & $1,477.000$ & $1,008.648$ & 0.253 \\
$\mathrm{CP}$ & 492.333 & 333.216 & 0.285
\end{tabular}

Source: Survey Results, 2020; advertisement believability (ADB) and customer patronage $(\mathrm{CP})$

Table 5 contains the results of the assessment of predictive relevance (Q2) which was obtained using tests of Greisser (1975) and Stone (974) that we conducted through the blindfolding technique. The table displays Q2 values of 0.253 and 0.285 for ADB and CP correspondingly. These results clearly show that the model falls within the high (Q2) predictive relevance region of 0.350 and offers vibrant support for the model's predictive relevance with regards to the endogenous constructs.

Test of Hypotheses

This section contains the tests of the hypotheses.

Table 6: The Results of Direct Effects from PLS Path Analysis

\begin{tabular}{lllllll}
\hline \multicolumn{1}{c}{ Variables } & $\begin{array}{c}\text { Origina } \\
\text { I } \\
\text { Sample }\end{array}$ & $\begin{array}{c}\text { Sample } \\
\text { Mean }\end{array}$ & $\begin{array}{c}\text { Std. } \\
\text { Dev. }\end{array}$ & $\begin{array}{c}\text { T } \\
\text { Stat. }\end{array}$ & P Values & Significant \\
\hline $\mathrm{ADB}=>\mathrm{CP}$ & 0.836 & 0.838 & 0.068 & 12.98 & $0.000 * * *$ & Yes \\
$\mathrm{BA}=>\mathrm{ADB}$ & -0.082 & -0.114 & 0.065 & 0.879 & 0.146 & No \\
$\mathrm{BA}=>\mathrm{CP}$ & -0.094 & -0.055 & 0.052 & 1.201 & 0.107 & No \\
\hline
\end{tabular}

Source: Survey Results, 2020; advertisement believability (ADB), customer patronage $(\mathrm{CP})$, and brand ambassador (BA)

Table 6 presents the result of the direct effects of the variables from a PLS path analysis. The table shows that the brand ambassador does not significantly affect customer patronage $(\beta=-0.055, t=1.201, p>0.10)$, while advertisement believability significantly affects that patronage $(\beta=0.838, t=12.981, p>0.01)$. Furthermore, the results indicate that the brand ambassador does not significantly affect advertisement believability $(\beta=$ $0.114, t=0.879, p>0.10)$.

Given these results, the hypothesis relating to the direct effect which states that the "brand ambassador does not have significant effect on customer patronage of Peak milk products in the metropolitan area of Kano" has support. 
Table 7: Indirect Effect from PLS Path Analysis

\begin{tabular}{cllcccc}
\hline Variables & OS & SM & Std. Dev. & T Stat. & P Values & Significant \\
\hline $\mathrm{BA}=>\mathrm{ADB}=>\mathrm{CP}$ & -0.063 & -0.0691 & 0.0667 & 0.836 & 0.124 & No \\
\hline
\end{tabular}

Source: Survey Results, 2020; advertisement believability (ADB), customer patronage (CP), and brand ambassador (BA)

Table 7 presents the results of the indirect effect from the path analysis and shows that there is an insignificant indirect effect. This result means that there is probably a nonmediation effect of advertisement believability on the influence of the brand ambassador on customer patronage $(\beta=-0.069, t=0.836, p>0.10)$. Consequently, it rejects the hypothesis relating to the indirect effect which states that "advertisement believability does not mediate the effect of a brand ambassador on customer patronage of Peak milk products in the metropolitan area of Kano".

Table 8: Summary of Test of Hypotheses

\begin{tabular}{lll}
\hline & Hypotheses & Decision \\
\hline $\mathrm{Ho}_{1}$ & $\begin{array}{l}\text { Brand ambassadors do not have significant effect on customer } \\
\text { patronage of Peak milk products in the metropolitan area of }\end{array}$ & Supported \\
Kano. & $\begin{array}{l}\text { Advertisement believability does not mediate the effect of a } \\
\text { brand ambassador on customer patronage of Peak milk } \\
\text { products in the metropolitan area of Kano. }\end{array}$ & \\
&
\end{tabular}

Source: Survey Results, 2020

\section{Discussion of Findings}

In this study, we examine the influence of a brand ambassador on customer patronage through the mediating role of advertisement believability. The extent of the variance explained by the study's exogenous variables on endogenous variables shows their predictive power to be 0.611 and 0.637 respectively for advertisement believability and customer patronage. These results demonstrate that the exogenous variables explain $61 \%$ and $64 \%$ of the problems in advertisement believability and customer patronage, while the remaining $39 \%$ and $36 \%$ could be due to other variables that were not considered in the study's model. With respect to effect size, advertisement believability has the higher effect of 0.801 and the highest t-value of 12.981 which shows that ADB has a significant effect on customer patronage.

The result also shows that the brand ambassador has an insignificant direct effect on customer patronage $(\beta=-0.055, t=1.201, p>0.10)$, while advertisement believability has a significant direct effect on customer patronage $(\beta=0.838, t=12.981, p>0.01)$. The findings of this study are consistent with the findings of the studies of Gaofu, Yating and Jing (2018); Radhi, Halim, Ratih, and Mokh (2019) and Garrett (2020) who discovered 
that the credibility and reputation of the brand ambassadors have a direct and positive effect on consumers' attitudes. The finding of the study also agrees with the findings of Lubna (2018), Gaofu, Yating and Jing (2018), Safi, Azouri and Azouri (2018), and Soniya and Santhosh (2018) that a brand ambassador's attractiveness is positively correlated with consumers' buying behavior and that the attractiveness of an ambassador can make an advertisement smarter and catchy.

Furthermore, the influence of a brand ambassador on customer patronage is not mediated by advertisement believability. The analyzed data show the standardized paths of the brand ambassador to advertisement believability $(\beta=-0.114, t=0.879, p>0.10)$ and to customer patronage $(\beta=-0.055, t=1.201, p>0.10)$ are not significant. This lack of significance means that the brand ambassador does not have direct influence either on advertisement believability or customer patronage. In addition, the standardized path of the brand ambassador to customer patronage through advertisement believability $(\beta=-$ $0.069, \mathrm{t}=0.836, \mathrm{p}>0.10)$ is insignificant. Hence, advertisement believability has no mediating effect on the influence of the brand ambassador on customer patronage. Further, this finding shows there is the presence of strong predictors as the result of the negative $\beta$ coefficient which is not unusual in a PLS-SEM analysis. This finding of this study contradicts the results of the work of Kim and Kim (2021) who discovered a mediating role of advertisement believability between cause proximity and message strategies on customers' attitude toward the advertisement.

Consequently, this study contributes to the theory by providing an empirical indication that the credibility of a brand ambassador can work alone to influence customer patronage without advertisement believability as a mediator.

\section{Conclusions and Recommendations}

This study was undertaken to examine the influence of a brand ambassador on customer patronage through the mediating role of advertisement believability. We concluded that while a brand ambassador's credibility has an insignificant direct effect on customer patronage, advertisement believability has a significant direct effect on customer patronage. We also found that advertisement believability plays no mediating role on the influence of a brand ambassador on customer patronage.

We now make the following recommendations on the basis of the above conclusions to guide the management of Friesland Campina WAMCO Nigeria PLC and other companies that use a brand ambassador to elicit patronage from target customers.

Managers of FMCGs should use a hybrid of a brand ambassador and believable advertisements to elicit the desired patronage from their target customers. FMCGs marketers could use brand ambassadors whose credibility is well known and develop the advertisement in a way that will make it believable to the target audience.

Managers of FMCGs should de-emphasis the supposed role of advertisement believability as a mediating factor on the influence of a brand ambassador on customer patronage. 


\section{References}

Abdullah, M., Bushan D., \& Dhruv, S. D (2017). Management based factors of sports celebrity endorsement and effect on brand image. Kozhikode Society \& Management Review,7(1),1-13.

Aamir, A., Gul, A., Iqra, A., \& Laila, E. (2018). The effect of celebrity endorsement on customer purchase intention: Current Economic and Management Research., 4(1), 1-10.

Albert, N., Ambroise, L., \& Valette-Florence, P. (2017). Consumer, brand, celebrity: Which congruency produces effective celebrity endorsements? Journal of Business Research, 81, $96 \quad-\quad 106$. https://www.sciencedirect.com/science/article/abs/pii/S0148296317302539

Anas. N. R., \& Pradipta, S. (2018). The effects of vlogger credibility as marketing media on brand awareness to customer purchase intention. Journal of Research in Management 1(2), 1 - 10.

Bagheri, H. \& Biglari, N. (2020). The role of consumers' attitude in the believability of commercial advertisements of endorser athletes. Sport Marketing Studies, 5172.

Beltramini, R. F. (1982). Advertising perceived believability scale. In Proceedings of the Southwestern Marketing Association. (p1-3). Kansas: Southwestern. Marketing Association.

Beltramini, R. F., \& Kenneth R. E. (1985). Perceived believability of research results information in advertising. Journal of Advertising, 14, 18-24.

Ben, W., \& Melissa, S. (2020). Brand ambassador: definition, job description, salary, \& more https://www.repsly.com/blog/field-team-management/brandambassador-job-definition-description-salary

Benita, L.T., \& Gordon, A. (2018). The influence of celebrity endorsement on consumer buying behavior in the Ghanaian fashion industry. Journal of Business and Marketing,1(1), 1-78

Blythe, J. (2013). The importance of understanding consumer behaviour. Retrieved online on 14th August, 2020,http://www.sagepub.com/upm/data/61706_blythe .

Carlson, B. D., Donavan, D. T., Deitz, G. D., Bauer, B. C., \& Lala, V. (2020). A customer- focused approach to improve celebrity endorser effectiveness. Journal of Business Research, 109, 221-235.

Carrillat, F. A., O'Rourke, A.-M., \& Plourde, C. (2019). Celebrity endorsement in the world of luxury fashion-when controversy can be beneficial. Journal of Marketing Management, 35(13-14), 1193-1213.

Daha, T.A., Acheampong, O., Bakare, A. S., \& Amanathan, K. (2018). Celebrity brand endorsement: A study on its impacts on generation Y-ers. International Journal of research in Marketing 11(3),415-427. 
Fachri. M. (2018). The influence of brand ambassador usage toward brand image. International Journal of research in Management Studies, 9(1),647-654.

Fenech, L. (2020). Factors affecting advert credibility and visit intention of restaurants in the social media environment. An unpublished Master Thesis submitted to university of Malta.

Festinger, L. (1954). A theory of social comparison processes. Human relations, $7(2)$, 117140.http://www2.psych.ubc.ca/ schaller/528Readings/Festinger1954.pdf

Fornell, C. \& Larcker, D.F. (1981). Structural equation models with unobservable variables and measurement error: Algebra and statistics. Journal of Marketing Research, 18, 382-388.

Gaofu, L., Yating, S., Jing, Y. (2018). The influence of advertising spokesperson image on consumers' purchase intention. International Conference on Educational Research, Economics, Management and Social Sciences,1(1) 692697.

Garrett, M. (2020). How brand ambassador on social media impact buyer decision https://www.hookit.com/insights/how-brand-ambassadors-on-socialmedia-impact-buyer-decisions/

Giridhar, K. V. (2012). Effects of celebrity endorsement on consumer buying behaviour and branding of a brand. Journal of Business and Management, 2(7), 92-102.

Goldsmith, R. E., Lafferty, B. A., \& Newell, S. J. (2000). Impact of corporate credibility and celebrity credibility on consumer reaction to advertisements and brands. Journal of Advertising, 29(3), 43-54.

Griffin, D., \& Cass, O. A. (2003) Antecedents and consequences of social issue advertising believability. In Anzmac Conference Proceeding, 1905-1912 Adelaide.

Hair, J., Black, W., Babin, B., \& Anderson, R. (2010). Multivariate Data Analysis: A Global Perspective (7th ed.). Pearson.

Hair Jr., J. F., Hult, G. T. M., Ringle, C., \& Sarstedt, M. (2016). A Primer on Partial Least Squares Structural Equation Modeling (PLS-SEM). Thousand Oaks, CA: Sage Publications. https://doi.org/10.15358/9783800653614.

Hovland, C., Janis, L., \& Kelley, H. (1953). Communication and Persuasion. New Haven, CT: Yale University Press.

Hovland, C., \& Weiss, W. (1951). The influence of source credibility on communication effectiveness. Public Opinion Quarterly, 15, 635- 650. doi:10.1086/266350

Hughes, R. (2013). Beyond the glitter, a career marked by hard work. Retrieved from http://www nytimes.com/2013/05/17/sports/soccer/beyond-glitterbeckhams-career-marked-by-hard-work. Html

Jisana, T. (2014). Consumer behaviour model. Journal of Commerce and Management, (5)1, 34-43. 
Jaiswal, A. K., \& Gupta, S. (2015). The influence of marketing on consumption behavior at the bottom of the pyramid. Journal of Consumer Marketing, 32(2), 113-124.

http://www.emeraldinsight.com/doi/abs/10.1108/JCM-05-20140996.

Kim, T. \& Kim, J. (2021). How spatial distance and message strategy in causerelated marketing ads influence consumers' ad believability and attitudes. Sustainability, 13(12), 6775. https://doi.org/10.3390/su13126775.

Kotler, P., \& Armstrong, G. (2015). Principles of marketing consumer: Markets and consumer buyer behaviour. (14th ed.). London: Prentice Hall.

Lim, J. S., Chock, T. M., \& Golan, G. J. (2020). Consumer perceptions of online advertising of weight loss products: the role of social norms and perceived deception. Journal of Marketing Communications, 26(2), 145-165.

Lisa, R., \& Astrid, K. (2018). Role of brand ambassador in increasing the interests of the customers of douj protect's products. Journal of Marketing. 15(3), 126-131.

Luh, G. P., Sari., D., Natasya, E., \& Hotlan, S. (2020). Effect of brand ambassador, brand image, and brand awareness on purchase decision of pantene shampoo in Surabaya, Indonesia. International Journal of Marketing,1(2),1-10. https://doi.org/10.1051/shsconf/20207601023

Lubna, Z. (2018). Celebrity advertisements and buying behavior of television viewers. Journal of Marketing 56(1),259-274.

Marium M. K. (2018). The effect of celebrity endorsement on consumer purchase intention. Journal of Business and Management, (2)1,1065-1082.

Matin, K. (2006). Consumer behaviour and advertising management: Consumer behaviour. New Delhi: New Age.

Marcela, M., John, G., Sandra, G., \& Piyush, S. (2019). Celebrity influences on consumer decision making: new insights and research directions. Journal of Marketing Management.4(1),1-10. doi: 10.1080/0267257X.2019.1632373.

Melinda, J., Butler, K., Rayens, M. K., Noland, M., Wiggins, A.T., \& Hahn, E. J. (2016). Recall and believability of the tips from former smokers' campaign among university students. American Journal of Health Education, 47(5), 324-331.

Mikuláš, P., \& Světlík, J. (2016). Execution of advertising and celebrity endorsement. communication today, 7(1), 92-103.

Mookda, R., Khan, S.W., Intasuwan, S. \& Chatchoung, S. (2020). The effect of celebrity endorsement on consumer purchase intention: The mediating role of brand loyalty. International Journal of Scientific and Research Publications,10(6), 1016-1021. doi: 10.29322/IJSRP.10.06. 2020.p102123

Mustapha, Y.I., Issa, B.O. \& Bello, O.F. (2021). Celebrity endorsement on consumers' perception and attitude towards Globacom telecommunication products in Ilorin metropolis. Vidyodaya Journal of Management, 07 (I), 61-80.

Ohanian, R. (1990). Construction and validation of a scale to measure celebrity endorsers' perceived expertise. Journal of Advertising, (19)3, 39-52. 
Oseyomon, E. P., \& Osio, E. (2018). Celebrity endorsement and customer purchase decision. Journal of Contemporary Research, 6 (2), 49-64.

Okorie N. \& Aderogba, A. (2011). The role of celebrity advertising on brand patronage. International Journal of Research in Computer application and management. 1(1), 27-34.

Phaik, N. C., Salmi, M. I., \& Yasmin, A. (2019). The impact of endorser and brand credibility on consumers' purchase intention. Business journal and marketing, 4, (2), $1-18$

Pui Yi, A. Y. (2012). Effects of celebrity endorsement on consumer purchasing intention of apparel products. Journal of Business Management,1(2), 1-175.

Qureshi, M. M., \& Malik, H. M. (2017). The impact of celebrity endorsement on consumer buying behavior. Advances in Social Sciences Research Journal, 4(3), 1-15.

Radhi A., Halim R. Ratih H. and Mokh. A.S (2019). Product differentiation, celebrity endorsement and purchase intention. Journal of Marketing,11(1), 275292

Safi, H., Azouri, M. \& Azouri, A. (2018). The effect of celebrity endorsement on consumer behavior: Case of the Lebanese jewelry industry, Arab Economic and Business Journal, 13(2), 190-196.

Salomon, M., Bamossy, G., Askegaard, S. \& Hogg, M. K. (2006). Consumer behaviour: An European perspective. (3rd ed.). England: Pearson prentice Hall.

Soesatyo, N. (2020). Credibility celebrity endorser of Top Coffee.'” Journal of Strategic Management and Marketing. 1 (2), 1-12.

Soniya, K., \& Santhosh R. R. (2018). Role of brand ambassadors in consumer buying behaviour of soft drink. International Journal of Engineering Development and Research,6(3), 1-10 (www.ijedr.org).

Sushil, K. R. \& Ashish, K. S. (2013). Celebrity attributes and influence on consumer behaviour. Pacific Business Review International, (11)5, 57-64.

Tehreem, Y. and Rizwan, K. (2016). Effects of online advertisement on consumer buying behavior of university students of Pakistan. Journal of Basic and Applied Scientific Research 6(11), 9-14.

Wenger A. (2015). Kanu Nwankwo will be remembered as the best English footballer of all time and he is the one of the most famous. Retrieved from http://www.telegraph.co.uk/sport/football/

Yamane, T. (1967). Statistics: An introductory analysis, (2nd ed.), New York: Harper and Row. 